\title{
Pajak dan Retrebusi Daerah
}

oleh:

*) Nuraini, S.E., M.M.

**)Dosen Luar Biasa STIE Muhammadiyah Jambi

\begin{abstract}
Abstrak
Pajak daerah dan retribusi daerah merupakan salah satu cara meningkatkan APBD apabila dijalankan dengan benar, sesuai dengan UU No.34 tahun 2000 tentang pajak daerah dan retribusi daerah.

Wajib pajak harus menjalankan kewajibannya membayar pajak yang ditetapkan yang harus sesuai dan tidak menjadi beban bagi pembayar pajak. Apabila ini berjalan dengan baik maka pembayaran pajak tersebut diatas akan berperan mengantar perekonomian masyarakat dan akhirnya kesejahteraan masyarakatpun akan meningkat.
\end{abstract}

Kata Kunci : Pajak, Pajak Daerah

\section{PENDAHULUAN}

\section{Latar Belakang}

Dalam rangka meningkatkan kemampuan keuangan daerah untuk melaksanakan otonomi, pemerintah melakukan berbagai kebijakan perpajakan daerah. Diantaranya dengan menetapkan Undang-Undang Nomor 34 tahun 2000 tentang perubahan atas Undang-Undang Nomor 18 tahun 1997 tentang pajak daerah dan retribusi daerah. Pemberian kewenangan dalam pengenaan pajak dan retribusi daerah diharapkan dapat lebih mendorong pemerintahan daerah untuk terus berupaya mengoptimalkan PAD, khususnya yang berasal dari pajak daerah dan retribusi daerah. Kebijakan pungutan pajak daerah berdasarkan Perda diupayakan tidak berbenturan dengan pungutan pusat (pajak maupun bea dan cukai) karena hal tersebut akan menimbulakan duplikasi pungutan yang pada akhirnya akan mendistorsi kegiatan perekonomian, Hal tersebut sebetulnya sudah diantisipasi dalam Undang-Undang Nomor 18 tahun 1997 tentang pajak daerah dan retribusi daerah sebagaimana di ubah dengan UndangUndang Nomor 34 tahun 2000 pasal 2 ayat (4) yang antara lain menyatakan bahwa objek pajak daerah bukan merupakan objek pajak pusat. Di negara-negara yang menganut paham hukum, segala sesuatu yang menyangkut pajak harus ditetapkan dalam peraturan perundangundangan. Dengan demikian, pemungutan pajak kepada rakyat tentunya harus disertai dengan perangkat peraturan perundang-undangan yang di sebut dengan hukum pajak. Di Indonesia, 
Undang-Undang Dasar 1945 Pasal 23A mengatur dasar hukum pemungutan pajak oleh negara. Pasal ini menyatakan bahwa pajak dan pungutan lain bersifat memaksa untuk keperluan negara di atur dengan Undang-Undang. Penyelenggaraan otonomi daerah akan dapat dilaksanakan dengan baik apabila didukung sumber-sumber pembiayaan yang memadai. Salah satunya adalah dengan meningkatkan kemampuan keuangan daerah bagi penyelenggara rumah tangganya. Sekalipun demikian, otonomi daerah dalam kerangka Negara Republik Indonesia, bukan hanya diukur dari jumlah PAD yang dapat dicapai, tetapi lebih dari itu yaitu sejauh mana pajak daerah dan retribusi daerah dapat berperan dalam mengatur perekonomian masyarakat agar dapat bertumbuh kembang, yang pada gilirannya dapat meningkatkan kesejahteraan masyarakat di daerah.

\section{Rumusan Masalah}

a. Apa saja yang menjadi sumber pendapatan daerah

b. Apa saja jenis pajak yang dapat ditarik pemerintahan daerah

c. Apa manfaat dari pajak daerah dan retribusi daerah

\section{Tujuan}
a. Mengetahui apa saja sumber pendapatan daerah
b. Mengetahui perundang-undangan tentang pajak daerah dan retribusi daerah
c. Dapat mengetahui apa manfaat dari pajak daerah dan retribusi daerah
d. Dapat mengetahui jenis, kriteria pajak daerah
e. Dapat mengetahui siapa saja yang harus membayar pajak

\section{PEMBAHASAN}

\section{A. Pajak Retribusi Daerah sebagai Sumber Pendapatan Daerah}

Dalam rangka meningkatkan kemampuan keuangan daerah untuk melaksanakan otonorni, pemerintah melakukan berbagai kebijakan perpajakan daerah. Diantaranya dengan menetapkan Undang-Undang Nomor 34 tahun 2000 tentang perubahan atas Undang-Undang Nomor 18 tahun 1997 tentang pajak daerah dan retribusi daerah. Pemberian kewenangan dalam pengenaan pajak dan retribusi daerah diharapkan dapat lebih mendorong pemerintahan daerah untuk terus berupaya mengoptimalkan PAD, khususnya yang berasal dari pajak daerah dan retribusi daerah. Berbagai macam respon 
timbul dari daerah-daerah diantaranya ialah bahwa pemberian keleluasaan yang diberikan kepada pemerintahan daerah untuk meningkatkan PAD melalui pajak daerah dan retribusi daerah berdasarkan Undang-Undang Nomor 34 tahun 2000 telah memperlihatkan hasil yang menggembirakan, yaitu sejumlah daerah berhasil mencapai peningkatan PAD-nya secara signifikan. Akan tetapi kreativitas pemerintahan daerah yang berlebihan dan tidak terkontrol dalam memungut pajak daerah dan retribusi daerah, akan menimbulkan dampak yang merugikan bagi masyarakat dan dunia usaha, yang pada gilirannya menyebabkan biaya ekonomi tinggi. Oleh karena itu Undang-Undang Nomor 34 tahun 2000 tetap memberikan batasan kriteria pajak daerah dan retribusi daerah yang dapat di pungut pemerintahan daerah.

\section{B. Prinsip dan Kriteria Perpajakan Daerah}

Kebijakan pungutan pajak daerah berdasarkan Perda diupayakan tidak berbenturan dengan pungutan pusat (pajak maupun bea dan cukai) karena hal tersebut akan menimbulkan duplikasi pungutan yang pada akhirnya akan mendistorsi kegiatan perekonomian. Hal tersebut sebetulnya sudah diantisipasi dalam Undang-Undang Nomor 18 tahun 1997 tentang pajak daerah dan retribusi daerah sebagaimana di ubah dengan Undang-Undang Nomor 34 tahun 2000 pasal 2 ayat (4) yang antara lain menyatakan bahwa objek pajak daerah bukan merupakan objek pajak pusat:

Prinsip-prinsip umum perpajakan daerah yang memenuhi kriteria umum tentang perpajakan daerah sebagai berikut:

1. Prinsip memberikan pendapatan yang cukup dan elastis, artinya dapat mudah naik turun mengikuti naik/turunnya tingkat pendapatan masyarakat.

2. Adil dan merata secara vertikal artinya sesuai dengan tingkatan kelompok masyarakat dan secara horizontal, artinya berlaku sama bagi setiap anggota kelompok masyarakat sehingga tidak ada yang kebal pajak.

3. Administrasi yang fleksibel artinya sederhana, mudah dihitung, memuaskan bagi wajib pajak.

4. Secara politis dapat diterima oleh masyarakat sehingga timbul motivasi dan kesadaran pribadi untuk membayar pajak.

5. Nondistorsi terhadap perekonomian: implikasi pajak atau pungutan yang hanya menimbulkan pengaruh minimal terhadap perekonomian. Pada dasarnya, setiap pajak 
atau pungutan akan menimbulkan suatu beban, baik bagi konsumen maupun produsen. Jangan sampai suatu pajak atau pungutan menimbulkan beban tambahan yang berlebihan sehingga merugikan masyarakat secara menyeluruh.

Untuk mempertahankan prinsip-prinsip tersebut, perpajakan daerah harus memiliki ciri-ciri tertentu, yaitu sebagai berikut:

1. Pajak daerah secara ekonomis dapat dipungut, berarti perbandigan antara penerimaan pajak harus lebih besar dibandingkan ongkos pemungutannya.

2. Relatif stabil, artinya penerimaan pajaknya tidak berfluktuasi terlalu besar, kadangkadang meningkat secara drastis dan ada kalanya menurun secara tajam.

3. Tak biasanya harus merupakan perpaduan antara prinsip keuntungan dan kemampuan untuk membayar.

Dalam kaitannya dengan pelaksanaan otonomi daerah, pemberian kewenangan untuk mengadakan pemungutan pajak, selain mempertimbangkan kriteria-kriteria perpajakan yang berlaku secara umum, seyogianya juga harus mempertimbangkan ketetapan suatu pajak sebagai pajak daerah. Pajak daerah yang baik merupakan pajak yang akan mendukung pemberian kewenangan kepada daerah dalam rangka pembiayaan desentralisasi. Untuk itu, pemerintah daerah dalam melakukan pungungutan pajak harus tetap "menempatkan" sesuai dengan fungsinya. Adapun fungsi pajak di kelompokan menjadi dua yaitu: fungsi budgeter dan fungsi regulator.

Funsi budgeter, yaitu apabila pajak sebagai alat untuk mengisi kas negara digunakan untuk membiayai kegiatan pemerintahan dan pembangunan. Fungsi regulator yaitu apabila pajak dipergunakan sebagai alat mengatur untuk mencapai tujuan, misalnya pajak minuman keras dimaksudkan agar rakyat menghindari atau mengurangi konsumsi minuman keras, pajak ekspor komoditas tertentu dalam rangka menghindari kelangkaan produk tersebut dalam negeri.

Menurut Teresa Ter-Minassian (1997), beberapa kriteria dan pertimbangan yang diperlukan dalam pemberian kewenangan perpajakan pada tingkat pemerintahan pusat, provinsi dan kabupaten/kota yaitu sebagai berikut:

1. Pajak yang dimaksudkan untuk tujuan stabilisasi ekonomi dan cocok untuk tujuan distribusi pendapatan seharusnya tetap menjadi tanggung jawab pemerintah pusat.

2. Basis pajak yang diserahkan kepada daeah seharusnya tidak terlalu mobile. Pajak daerah yang sangat mobile akan mendorong pembayar pajak merelokasi usahanya 
dari daerah yang beban pajaknya tinggi ke daerah yang beban pajaknya rendah. Sebaliknya, basis pajak yang tidak terlalu mobile akan mempermudah daerah untuk menetapkan tarif pajak yang berbeda sebagai cerminan dari kemampuan masyarakat. Untuk alasan ini, pajak konsumsi di banyak negara diserahkan kepada daerah hanya karena pertimbangan wilayah daerah yang cukup luas (seperti provinsi di canada). Dengan demikian, basis pajak mobile merupakan persyaratan utama untuk mempertahankan di tingkat pemerintahan yang lebih tinggi. (pusat/provinsi).

3. Basis pajak yang distribusinya sangat timpang antar daerah, seharusnya diserahkan kepada pemerintahan pusat.

4. Pajak daerah seharusnya visible dalam arti bahwa pajak seharusnya jelas bagi pembayar pajak daerah, objek dan subjek pajak dan besarnya pajak terutang dapat dengan mudah dihitung sehingga dapat mendorong akuntabilitas daerah.

5. Pajak daerah seharusnya tidak dapat dibebankan kepada penduduk daerah lain karena akan memperlemah hubungan antara pembayar pajak dan pelayanan yang diterima (pajak adalah fungsi dari pelayanan).

6. Pajak daerah seharusnya dapat menjadi sumber penerimaan yang memadai untuk menghindari ketimpangan fiskal vertikal yang besar. Hasil penerimaan, idealnya, harus elastis sepanjang waktu dan seharusnya tidak terlalu berfluktuasi.

7. Pajak yang diserahkan kepada daerah seharusnya relatif mudah di administrasikan atau dengan kata lain perlu pertimbangan efisiensi secara ekonomi berkaitan dengan kebutuhan data, seperti identifikasi jumlah pembayar pajak, penegakan hukum dan komputerisasi.

8. Pajak dan retribusi berdasarkan prinsip manfaat dapat digunakan secukupnya pada semua tingkat pemerintahan, tetapi penyerahan kewenangan pemungutannya kepada daerah akan tetap sepanjang manfaatnya dapat dilokasikan bagi pembayar pajak lokal.

\section{Ketentuan Pungutan Pajak Daerah dan Retribusi Daerah}

Di negara-negara yang menganut paham hukum, segala sesuatu yang menyangkut pajak harus ditetapkan dalam peraturan perundang-undangan. Dengan demikian, pemungutan pajak kepada rakyat tentunya harus disertai dengan perangkat peraturan perundang-undangan yang di sebut dengan hukum pajak. Di Indonesia, Undang-Undang Dasar 1945 Pasal 23A mengatur dasar hukum pemungutan pajak oleh negara. Pasal ini 
menyatakan bahwa pajak dan pungutan lain bersifat memaksa untuk keperluan negara di atur dengan Undang-Undang.

Pengaturan kewenangan pengenaan pemungutan pajak daerah dan retribusi daerah dalam Undang-Undang Nomor 18 tahun 1997 yang mulai berlaku pada tahun 1998 dianggap kurang memberikan peluang kepada daerah untuk mengadakan pungutan baru. Walaupun memberikan kewenangan kepada daerah, undang-undang tersebut harus ditetapkan dengan peraturan pemerintahan sehingga saat Undang-Undang Nomor 18 tahun 1997 berlaku, belum ada satupun daerah yang mengusulkan pungutan baru karena menganggap hal tersebut sulit dilakukan. Selain itu, pengaturan agar Perda tentang pajak daerah dan retribusi daerah harus mendapat pengesahan dari pusat juga dianggap telah mengurangi otonomi daerah. Dengan di ubannya Undang-Undang Nomor 18 tahun 1997 menjadi Undang-Undang Nomor 34 tahun 2000, diharapkan pajak daerah dan retribusi daerah akan menjadi salah satu PAD yang penting guna membiayai penyelenggaraan dan pembangunan daerah. Undang-Undang Nomor 34 tahun 2000 dan peraturan pemerintah pendukungnya yaitu PP Nomor 65 tahun 2001 tentang pajak daerah dan PP Nomor 66 tahun 2001 tentang retribusi daerah menjelaskan perbedaan antara jenis pajak daerah yang di pungut oleh provinsi dan jenis pajak yang dipungut oleh kabupaten/kota. Pajak provinsi ditetapkan sebanyak empat jenis, yaitu:

1. Pajak kendaraan bermotor dan kendaraan di atas air (PKB dan KAA)

2. Bea batik nama kendaraan bermotor dan kendaraan di atas air (BBNKB dan KAA)

3. Pajak bahan bakar kendaraan bermotor (PBBKB)

4. Pajak pengambilan dan pemanfaatan air bawah tanah dan permukaan (P3ABT dan AP)

Jenis pajak provinsi bersifat limitatif yang berarti provinsi tidak dapat memungut pajak lain, selain yang telah di tetapkan, dan hanya dapat menambah jenis retribusi lainnya sesuai dengan kriteria yang ditetapkan undang-undang. Adanya pembatasan jenis pajak yang dapat dipungut oleh provinsi sebagai daerah otonom yang terbatas, yang hanya meliputi kewenangan dalam bidang pemerintahan yang bersifat lintas daerah kabupaten/kota dan kewenangan yang tidak atau belum dapat dilaksanakan oleh daerah kabupaten/kota, serta kewenangan bidang pemerintahan tertentu. Sekalipun demikian, dalam pelaksanaannya provinsi dapat memutuskan untuk tidak memungut jenis pajak yang telah ditetapkan tersebut jika dipandang hasilnya kurang memadai. Berkaitan 
dengan besarnya tarif, berlaku definitif untuk pajak provinsi yang ditetapkan secara seragam di seluruh Indonesia dan diatur dalam PP Nomor 65 tahun 2001.

Sementara itu, pemerintah daerah kabupaten/kota diberi kewenangan untuk memungut tujuh jenis pajak, yaitu:

a. Pajak hotel;

b. Pajak restauran;

c. Pajak hiburan;

d. Pajak reklame;

e. Pajak penerangan jalan;

f. Pajak pengambilan bahan galian golongan $\mathrm{C}$;

g. Pajak parkir.

Jenis pajak kabupaten/kota tidak bersifat limitatif, artinya kabupaten/kota diberi peluang untuk menggati potensi sumber-sumber keuangannya, selain yang ditetapkan secara eksplisit dalam Undang-Undang Nomor 34 tahun 2000, dengan menetapkan sendiri pajak yang bersifat spesifik dengan memerhatikan kriteria yang ditetapkan dalam undang-undang tersebut, kriteria yang dimaksud adalah sebagai berikut:

1. Bersifat pajak dan bukan retribusi;

2. Objek pajak terletak atau terdapat di wilayah kabupaten/kota yang bersangkutan dan mempunyai mobilitas yang cukup rendah serta hanya melayani masyarakat diwilayah daerah kabupaten/kota yang bersangkutan;

3. Objek dan dasar pengenaan pajak tidak bertentangan dengan kepentingan umum;

4. Objek pajak bukan merupakan objek pajak provinsi dan/atau objek pajak pusat;

5. Potensinya memadai;

6. Tidak memberikan darnpak ekonomi yang negatif;

7. Memerhatikan aspek keadilan dan kemampuan masyarakat;dan

8. Menjaga kelestarian lingkungan.

Besarnya tarif yang berlaku definitif untuk pajak kabupaten/kota ditetapkan dengan peraturan daerah, tetap tiddak boleh lebih tinggi daripada tarif maksimum yang telah di tentukan dalam Undang-Undang tersebut. Dengan adanya pemisahan jenis pajak yang dipungut oleh provinsi dan yang dipungut oleh kabupaten/kota diharapkan tidak adanya pengenaan pajak berganda. 
Dalam rangka pengawasan, perda tentang pajak dan retribusi yang di terbitkan oleh pemerintahan daerah harus disampaikan kepada pemerintah pusat paling lambat lima belas hari sejak ditetapkan. Dalam hal Perda tersebut bertentangan dengan kepentingan umum dan/atau peraturan perundang-undangan yang lebih tinggi, pemerintah pusat melalui mentri dalam negeri dengan pertimbangan mentri keuangan dapat membatalkan perda tersebut dalam kurun waktu satu bulan sejak diterimanya peraturan tersebut. Ketentuan-ketentuan tersebut di atur dalam pasal 5A dan pasal 25A Undang-Undang Nomor 34 tahun 2000 juncto pasal 80 ayat (2) PP Nomor 65 tahun 2001 dan pasal 17 ayat (2) PP Nomor 66 tahun 2001. Sekalipun demikian, walaupun perda-perda tersebut sudah dibatalkan oleh pemerintah pusat, pemerintah daerah dapat mengajukan keberatan kepada Mahkamah Agung (MA) segera setelah mengajukannya kepada pemerintah berdasarkan PP Nomor 20 tahun 2001 tentang pembinaan dan pengawasan atas penyelenggaraan Pemerintahan Daerah.

\section{Peningkatan Penerimaan Pajak Daerah}

Penggalian sumber-sumber keuangan daerah khususnya yang berasal dari pajak daerah pada dasarnya perlu memerhatikan dua hal, yaitu dasar pengenaan pajak dan tarif pajak. Pemerintahan daerah cenderung menggunakan tarif yang tinggi agar memperoleh total penerimaan pajak daerah yang maksimal. Pengenaan tarif pajak yang lebih tinggi, secara teoritis tidak selalu menghasilkan total penerimaan maksimum. Hal ini bergantung pada respon wajib pajak, permintaan, dan penawaran barang yang dikenakan tarif pajak lebih tinggi. Formulasi model ini dikenal sebagai Model Leviathan.

Model Leviathan ini memberikan pelajaran kepada kita bahwa peningkatan penerimaan pajak daerah tidak harus dicapai dengan mengenakan tarif pajak yang terlalu tinggi, tetapi dengan pengenaan tarif pajak yang lebih rendah dikombinasikan dengan struktur pajak yang meminimalkan barang terhadap pengenaan pajak sedemikian rupa, sehingga mencapai total penerimaan maksimum. Model Laviathan ini dapat dikembangkan untuk menganalisis hubungan lebih lanjut antara tarif dan dasar pengenaan pajak untuk mencapai total penerimaan maksimal. 


\section{E. Peranan Pajak Daerah dan Retribusi Daerah dalam Mendukung Pembiayaan Daerah}

Pajak daerah dan retribusi daerah merupakan salah satu bentuk peran serta masyarakat dalam penyelenggaraan otonomi daerah. Pajak daerah dan retribusi daerah ini merupakan sumber pendapatan daerah yang penting untuk membiayai penyelenggaraan pemerintahan dan pembangunan daerah. Permasalahan yang dihadapi oleh daerah pada umumnya dalam kaitan penggalian sumber-sumber pajak daerah dan retribusi daerah, yang merupakan salah satu komponen PAD, belum memberikan kontribusi yang signifikan terhadap penerimaan daerah secara keseluruhan. Untuk mengantisifasi desentralisasi dan proses otonomi daerah, pungutan pajak dan retribusi daerah masih belum dapat diandalkan oleh daerah sebagai sumber pembiayaan desentralisasi. Keadaan ini diperlihatkan dari suatu studi yang dilakukan oleh LPEM-UI bekerja sama dengan clean Urban Project bahwa banyak permasalan yang terjadi di daerah berkaitan dengan penggalian dan peningkatan PAD, terutama hal ini disebabkan oleh hal berikut:

1. Relatif rendahnya basis pajak dan retribusi daerah

Berdasarkan Undang-Undang Nomor 34 tahun 2000 daerah kabupaten/kota dimungkinkan untuk menetapkan jenis pajak dan retribusi baru. Akan tetapi, melihat kriteria pengadaan pajak baru sangat ketat, khususnya kriteria pajak daerah tidak boleh tumpang tindih dengan pajak pusat dan pajak provinsi, diperkirakan daerah memiliki basis pungutan yang relatif rendah dan terbatas, serta bervariasi antardaerah. Rendahnya basis pajak ini untuk sebagian daerah berarti memperkecil kemampuan manuver keuangan daerah dalam menghadapi krisis ekonomi.

2. Perannya yang tergolong kecil dalam total penerimaan daerah

Sebagian besar penerimaan daerah masih berasal dari bantuan pusat. Dari segi upaya pemungutan pajak, banyaknya bantuan dan subsidi ini mengurangi "negosiasi" daerah terhadap pusat untuk memperoleh tambahan bantuan.

\section{Kemampuan administrasi pemungutan di daerah yang masih rendah}

Hal ini mengakibatkan pernungutan pajak cenderung dibebani oleh biaya pungut yang besar. PAD masih tergolong memiliki tingkay buoyancy yang rendah. Salah satu sebabnya adalah diterapkannya sistem "target" dalam pungutan daerah. Sebagai akibatnya, beberapa daerah lebih condong memenuhi target tersebut. Walaupun dari 
sisi pertumbuhan ekonomi, pemasukan pajak dan retribusi daerah dapat melampaui target yang ditetapkan.

4. Kemampuan perencanaan dan pengawasan keuangan yang lemah

Hal ini mengakibatkan kebocoran yang sangat berati bagi daerah. Selama ini, peranan PAD dalam membiayai kebutuhan pengeluaran daerah sangat kecil dan bervariasi antardaerah, yaitu kurang dari 10\% hingga 50\%. Sebagian besar daerah provinsi hanya dapat membiayai kebutuhan pengeluarannya kurang $10 \%$.

5. Variasi dalam penerimaan diperparah lagi dengan sistem bagi hasil (bagi hasil didasarkan pada daerah penghasil sehingga hanya menguntungkan daerah tertentu). Demikian pula, distribusi pajak antar daerah juga sangat timpang karena basis pajak antar daerah juga sangat bervariasai, Peranan pajak dan retribusi daerah dalam pembiayaan yang sangat rendah dan bervariasi juga terjadi karena adanya perbedaan yang sangat besar dalam jumlah penduduk, keadaan geografis (berdampak pada biaya yang relatif mahal), dan kemampuan masyarakat sehingga biaya penyediaan pelayanan kepada masyarakat menjadi sangat bervariasi.

Tidak signifikannya peran PAD dalam anggaran daerah tidak lepas dari sistem tax assignment di Indonesia yang masih memberikan kewenangan penuh kepada pemerintah pusat untuk mengumpulkan pajak-pajak potensial (yang tentunya dilakukan berdaasarkan pertimbangan-pertimbangan tertentu), seperti pajak penghasilan, pajak pertambahan nilai dan bea masuk. Kenyataan menunjukan bahwa distribusi kewenangan perpajakan antara daerah dan pusat sangat timpang, yaitu jumlah penerimaan pajak yang dipungut oleh dearah hanya sebesar 3,39\% dari total penerimaan pajak (pajak pusat dan pajak daerah). Ketimpangan dalam penguasaan sumber-sumber penerimaan pajak tersebut memberikan petunjuk bahwa pertimbangan keuangan antara pemerintahan pusat dan daerah di Indonesia dari sisi revenue assignment masih terlalu sentralistis.

\section{F. Optimalisasi Pungutan Pajak dan Retribusi Daerah dalam Rangka Meningkatkan}

\section{Kemampuan Keuangan Daerah}

Ciri utama yang menunjukan suatu daerah otonom mampu berotonomi, terletak pada kemampuan keuangan daerah. Artinya, daerah otonom memiliki kewenangan dan kemampuan untuk menggali sumber-sumber keuangan sendiri, mengelola dan menggunakan keuangan sendiri yang cukup memadai untuk membiayai penyelenggaraan 
pemerintahan daerahnya. Kebergantungan kepada bantuan pusat harus seminimal mungkin, sehingga PAD, khususnya pajak dan retribusi daerah, menjadi bagian sumber keuangan terbesar, yang didukung oleh kebijakan pertimbangan keuangan ousat dan daerah sebagai prasyarat mendasar dalam sistem pemerintahan negara.

Berkaitan dengan hal tersebut, optimalisasi sumber-sumber PAD perlu dilakukan untuk meningkatkan kemampuan keuangan daerah. Untuk itu, diperlukan intensifikasi dan ekstensifikasi subjek dan objek pendapatan.

Dalam jangka pendek, kegiatan yang paling mudah dan dapat segera dilakukan adalah melakukan intensifikasi terhadap objek atau sumber pendapatan daerah yang sudah ada, terutama melalui pemanfaatan teknologi dan informasi. Dengan melakukan efektivitas dan efisiensi sumber atau objek pendapatan daerah, produktivitas PAD akan meningkat tanpa harus melakukan perluasan aumber atau objek pendapatan baru yang mendapatkan studi, proses, dan waktu yang panjang. Dukungan teknologi informasi secara terpadu guna mengintensifkan pajak mutlak diperlukan karena sistem pemungutan pajak yang dilaksanakan selama ini cenderung tidak optimal. Masalah konvensional dan masih banyak sistem berjalan secara varsial sehingga informasi yang disampaikan tidak konsisten, versi data yang berbeda, dan data tidak up-to-date. Pemasalahan pada sistem pungutan pajak cukup banyak, misalnya data wajib pajak/retribusi, penetapan jumlah pajak, jumlah tagihan pajak, dan target pemenuhan pajak yang tidak optimal.

Secara umum, upaya yang perlu dilakukan oleh pemerintah daerah dalam rangka meningkatkan pendapatan daerah melalui optimalisasi intensifikasi pemungutan pajak daerah dan retribusi daerah, antara lain dengan cara-cara berikut:

1. Memperluas basis penerimaan

Tindakan yang dilakukan untuk memperluas basis penerimaan yang dapat dipungut oleh daerah, yang dalam perhitungan ekonomi dianggap potensial, yaitu mengidentifikasi pembayar pajak baru/potensial dan jumlah pembayar pajak, memperbaiki basis data dan objek, memperbaiki penilaian, menghitung kapasitas penerimaan dari setiap jenis pungutan.

2. Memperkuat proses pemungutan

Upaya yang dilakukan dalam memperkuat proses pemungutan, yaitu antara lain mempercapat penyusunan Perda, mengubah tarif, khususnya tarif retribussi dan peningkatan SDM. 


\section{Meningkatkan pengawasan}

Hal ini dapat ditingkatkan, yaitu dengan melakukan pemeriksaan secara dadakan dan berkala, memperbaiki proses pengawasan, menerapkan sanksi terhadap penunggak pajak dan sanksi terhadap pihak fiskus, serta meningkatkan pembayaran pajak dan pelayanan yang diberikan oleh daerah.

4. Meningkatkan efisiensi administrasi dan menekan biaya pemungutan.

Tindakan yang dilakukan oleh daerah, yaitu memperbaiki prosedur administrasi pajak melalui penyederhanaan administrasi pajak, meningkatkan efisiensi pemungutan dari setiap jenis pemungutan.

5. Meningkatkan kafasitas penerimaan melalui perencanaan yang lebih baik.

Hal ini dapat dilakukan dengan meningkatkan koordinasi dengan intasi terkait di daerah. Selanjutnya, ekstensifikasi perpajakn juga dapat dilakukan, yaitu melalui kebijaksanaan pemerintah untuk memberikan kewenangan perpajakan yang lebih besar kepada daerah pada mas mendatang. Untuk itu, perlu perubahan dalam sistem perpajakan Indonesia melalui sistem pembagian langsung atau beberapa basis pajak pemerintahan pusat yang lebih tepat di pungut oleh daerah.

Berkaitan dengan hai tersebut, ada gagasan yang berkembang dikalangan para pakar internasional, akademisi maupun praktisi di bidang desentralisasi fiskal, untuk menambah taxing power kepada pemerintah daaerah. Hal ini dapat dilihat dari gambaran consolidated revenues APBD dan APBN (APBD kabupaten/kota + provinsi+ penerimaan dalam negeri dalam APBN), porsi PAD hanya sebesar 5,30\% dari total consolidated revenues, dipihak lain pengeluaran yang menjadi tanggung jawab daerah sekitar 30\% dari consolidated expenditures. Gambaran porsi PAD terhadap total consolidated revenues yang hanya $5,30 \%$ tersebut menunjukan berapa sentralistisnya sisi penerimaan antara kabupaten/kota dan provinsi disatu pihak dan penerimaan dalam negeri dalam APBN dipihak lain. Sebagai perbandingan yang sama, masing-masing untuk developing countries, transition countries, dan OECD countries rata-rata sebesar 9,27\%, 16,59\% dan 19,13\%. Keadaan ini kurang mendukung akuntabilitas dari penggunaan anggaran daerah, dan keterbatasan dana transfer dari pusat untuk membiayai kebutuhan daerah idealnya dapat ditutup oleh daerah dengan menyesuaikan basis pajak atau tarif pajak daerahnya.

Untuk itu, perlu dicarikan upya untuk meningkatkan taxing power daerah, antara lain melalui pengaiihan sepenuhnya beberapa pajak pusat kepada daerah (artinya daerah 
sepenuhnya menetapkan basis pajak, tarif ataupun administrasi pemungutannya), pengaiihan sebagian penerimaan negara bukan pajak (PNBP) kepada daerah dan kebijakan Iain-lain sharring tax dan piggy backing system. Kabupaten/kota perlu diberikan tambahan pendapatan dengan memberikan kewenangan penuh memungut pajak sampai dengan besaran tertentu. Pemerintah kabupaten/kota diberikan wewenang untuk menetapkan dasar pengenaan pajak (tax-base) dan tarif sampai dengan batas tertentu atas kedua jenis pajak tersebut, meskipun untuk sementara aktu administrasinya akan tetap dilakukan oleh pemerintah pusat,. Kebijakan ini sekaligus diharapkan dapat menghilangkan upaya daerah untuk menggali sumber-sumber PAD yang berdampak distorrsif terhadap perekonomian. Dipihak lain, dilihat dari sisi kewenangan yang menjadi tanggung jawab daerah, Indonesia tergolong negara yang melaksanakan desentralisasi dengan suatu proses yang big-bang. Hal ini dapat dilihat dari pergeseran expenditure assignment yang dilaksanakan oleh daerah pada tahun 1990-an sebesar $16.59 \%$ dari total consolidated expenditure (APBD+APBN) meningkat menjadi 27,78 pada tahun 2001 .

Berdasarkan uraian tersebut, penyelenggaraan otonomi daerah akan dapat dilaksanakan dengan baik apabila didikung sumber-sumber pembiayaan yang memadai. Salah satunya adalah dengan meningkatkan kemampuan keuangan daerah bagi penyelenggara rumah tangganya. Sekalipun demikian, otonomi daerah dalam kerangka Negara Republik Indonesia, bukan hanya diukur dari jumlah PAD yang dapat dicapai, tetapilebih dari itu yaitu sejauh mana pajak daerah dan retribusi daerah dapat berperan dalam mengatur perekonomian masyarakat agar dapat bertumbuh kembang, yang pada gilirannya dapat meningkatkan kesejahteraan masyarakat di daerah.

\section{KESIMPULAN}

Kesimpulan yang dapat saya tarik dari pembahasan di atas dalah bahwa pajak daerah dan retribusi daerah merupakan salah satu cara meningkatkan APBD tapi pajak dan retribusi daerah itu hams dilaksanakan dengan benar dan adil oleh pemerintah maupun pembayar pajak, di kenakannya sanksi terhadap orang yang menunggak atau menyalahkan aturan adalah hal yang benar, seperti yang terdapat pada Undang-Undang Nomor 34 tahun 2000 tentang pajak daerah dan retribusi daerah. seperti juga dijelaskan di atas bahwa terdapat kategori-kategori atau kriteria-kriteria pajak. Berapa tarif pajak yang di tetapkan yang harus 
sesuai tidak menjadi beban bagi pembayar pajak, di jelaskan juga jenis-jenis pajak apa saja yang di ambil seperti pajak perhotelan, pajak hiburan, pajak restoran, pajak reklame, pajak penerangan jalan, pajak pengambilan bahan galian golongan $\mathrm{C}$ dan pajak parkir. Di harapkan dengan adanya pembayaran pajak dan retribusi daerah yang tidak membebani masyarakat pembayar pajak dapat berperan mengatur perekonomian masyarakat agar dapat bertumbuh kembang yang pada gilirannya dapat meningkatkan kesejahteraan masyarakat di daerah.

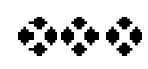

\section{DAFTAR PUSTAKA}

Atep Adya Barata. Perpajakan. Bandung : Armico 1994. U

Kamus Besar Bahasa Indonesia. 1994.

Muhammad Teguh, Metodologi Penelitian Ekonomi, Teori dan Aplikasi Jakarta PT Raja Grafindo Persada, 2001.

Sadono Sukirno, Pengantar Teori Mikroekonomi Edisi Ke II . Jakarta PI .Raja Grafindo Persada 1997.

Sadono Sukirno, Ekonomi Pembangunan, Masalah, Proses dan Dasar Kebijaksanaan, Edisi Revisi II. Jakarta Fakultas Ekonomi UI 1994

Suharsimi Ankunto.Prosedur Penelitian Suatu Pendekatan Praktek Edisi revisi III Jakarta : Rineka Cipta 1996.

Sudarsono. Antara Bea Meterai dan Kebijaksanaan Pajak. Jakarta : Rineka Cipta 1994

UU No. 18 Pajak Daerah dan Retribusi, Pajak Pengambilan dan Pengolahan Bahan Galian Golongan C, 1997.

UU No. 34, Tahun 2000, Tentang Pajak Daerah dan Retrebusi Daerah.

Wojo Wasito. Kamus bahasa Indonesia Edisi Revisi. Malang : CV. Pengarang 1997.

Yadianto. Kamus Umum Bahasa Indonesia : M2S Bandung 1997. 